\title{
Sistem Pendukung Keputusan Dalam Menentukan Kinerja Pengajar Dengan Metode Additive Ratio Assessment (ARAS)
}

\author{
Chrisnatanius Tarigan*, Erika Fahmi Ginting**, Rendy Syahputra** \\ * Program Studi Sistem Informasi, STMIK Triguna Dharma \\ ** Program Studi Sistem Informasi, STMIK Triguna Dharma
}

\begin{tabular}{|c|c|}
\hline Article Info & ABSTRACT \\
\hline $\begin{array}{l}\text { Keyword: } \\
\text { ARAS } \\
\text { Kinerja Tenaga Pengajar } \\
\text { Kriteria } \\
\text { Sistem Pendukung Keputusan } \\
\text { Perangkingan }\end{array}$ & $\begin{array}{l}\text { Tenaga pengajar memiliki peran penting untuk mendidik dan membimbing } \\
\text { siswa menjadi sumber daya manusia yang berkualitas. Kualitas pengajaran dan } \\
\text { standar akademik perlu dievaluasi dan ditingkatkan untuk memperoleh hasil } \\
\text { pembelajaran yang maksimal. SMP Negeri } 3 \text { Satu Atap Selesai rutin } \\
\text { melaksanakan evaluasi atau penilaian kinerja terhadap seluruh tenaga pengajar, } \\
\text { tetapi masih menggunakan metode manual. Oleh karena itu dalam penyelesaian } \\
\text { tersebut perlu dibuat suatu sistem pendukung keputusan dengan menggunakan } \\
\text { metode Additive Ratio Assessment (ARAS), yang merupakan metode } \\
\text { pengambilan keputusan dalam perangkingan kriteria. Hal ini diharapkan dapat } \\
\text { membantu kepala sekolah dalam menentukan kinerja tenaga pengajar terbaik } \\
\text { dari lima kriteria, yaitu pedagogik, kepribadian, sosial, professional dan } \\
\text { tanggung jawab. Hasil yang diperoleh dari perhitungan dengan metode ARAS, } \\
\text { kinerja tenaga pengajar terbaik adalah Novrini, S.Pd. }\end{array}$ \\
\hline & $\begin{array}{r}\text { Copyright } \odot 2022 \text { STMIK Triguna Dharma. } \\
\text { All rights reserved. }\end{array}$ \\
\hline $\begin{array}{l}\text { Corresponding Author:* } \\
\text { Nama : Chrisnatanius Tarigan } \\
\text { Program Studi Sistem Informasi } \\
\text { STMIK Triguna Dharma } \\
\text { Email: christarigan90@ gmail.com }\end{array}$ & \\
\hline
\end{tabular}

\section{PENDAHULUAN}

Kegiatan belajar mengajar perlu dilakukan evaluasi untuk mengetahui hasil pembelajaran yang sudah dilaksanakan dan mengetahui kinerja tenaga pengajar selama menjalankan kegiatan belajar mengajar. Hal ini perlu dilakukan karena tenaga pengajar memiliki peran penting membantu para siswa untuk mencapai pembelajaran dan pribadi yang baik. SMP Negeri 3 Satu Atap Selesai rutin melaksanakan evaluasi atau penilaian kinerja terhadap seluruh tenaga pengajar. Sistem penilaian kinerja guru yang dilaksanakan masih dengan metode manual dan belum memiliki model standar dalam penilaian, sehingga proses pemilihan guru berprestasi masih terkesan lambat dan subjektif.

Manajemen penilaian kinerja tenaga pengajar perlu dilakukan untuk memperoleh keputusan yang tepat. Salah satu cara yang dapat dilakukan dengan membuat aplikasi yang berbasis pengetahuan untuk mendukung proses pengambilan keputusan. Sistem Pendukung Keputusan (Decision Support System) merupakan system berbasis komputer yang membantu para pembuat keputusan dalam proses pengambilan keputusan. Sistem Pendukung Keputusan (SPK) sebagai sistem informasi berbasis komputer yang adaptif, interaktif, dan fleksibel untuk meningkatkan kualitas pengambilan keputusan.

Metode SPK yang digunakan untuk penilaian kinerja tenaga pengajar ini adalah Metode Additive Ratio Assessment (ARAS). Menerapkan metode ARAS akan lebih mudah karena metode ARAS secara garis besar banyak melakukan perangkingan dengan cara membandingkan dengan alternatif lainnya sehingga mendapatkan hasilnya lebih akurat dan tepat sasaran [1]. ARAS diperkenalkan oleh Zavadkas dan Turskis [2], menggunakan ARAS untuk kasus evaluasi iklim mikro di ruang kantor dan memperoleh hasil yang mudah dalam mengevaluasi dan merangking keputusan alternatif. Metode ARAS menggunakan nilai utilitas (Ki) tertinggi untuk mendapatkan pilihan terbaik.

Beberapa penelitian terdahulu yang meggunakan metode ARAS dalam mengambil keputusan, yaitu penelitian yang berjudul "Penerapan Metode ARAS Guna Mendukung Keputusan Produk Unggulan Daerah" 
[3]. Penelitian ini menyatakan dengan metode ARAS mendapatkan hasil perangkingan berdasarkan jumlah dominasi penghasilan menghasilkan perangkingan yang lebih parsial dan sensitif dibandingkan perangkingan berdasarkan level. Penelitian yang berjudul "Sistem Pendukung Keputusan Pemilihan Polisi Militer Terbaik Menggunakan Metode Additive Ratio Assessment (ARAS)" [4].Penelitian ini menerapkan lima variabel input untuk memberi kemudahan bagi pimpinan dalam menentukan polisi militer yang terbaik.

Adapun tujuan dari penelitian ini untuk membangun sistem yang dapat membantu proses penilaian kinerja tenaga pengajar yang dilakukan pada SMP Negeri 3 Satu Atap Selesai dengan metode ARAS.

\section{METODE PENELITIAN}

Metode yang digunakan dalam penelitian adalah metode Additive Ratio Assessment (ARAS). . Berikut ini beberapa langkah yang dilakukan, yaitu: (1) teknik pengumpulan data (Data Collecting), dengan melakukan observasi, dan wawancara langsung di SMP Negeri 3 Satu Atap Selesai untuk memperoleh data tenaga pengajar dan kriteria penilaian. (2) Studi literatur.

Di dalam metode perancangan sistem penelitian ini, terkhusus untuk software atau perangkat lunak, digunakan sebuah metode perancangan system, yaitu metode waterfall atau algoritma air terjun. Berikut ini adalah fase-fase yang dilakukan untuk merancang sistem menggunakan metode waterfall atau algoritma air terjun, yaitu :

1. Analisis Masalah dan Kebutuhan

Pada fase ini, ditentukan titik awal permasalahan sebenarnya, dan elemen apa saja yang dibutuhkan dalam pemilihan tenaga pengajar terbaik pada SMP Negeri 3 Satu Atap Selesai.

\section{Desain Sistem}

Tahap desain dilakukan dengan menerjemahkan kebutuhan perangkat lunak berdasarkan dari hasil analisis kebutuhan ke dalam bentuk desain. Ada beberapa jenis pemodelan perangkat lunak, yaitu (1) pemodelan system dengan Unified Modelling Languange, (2) pemodelan menggunakan flowchart system.

3. Pembangunan Sistem

Pada fase ini merupakan tahap menerjemahkan desain system ke dalam perangkat lunak berdasarkan desain yang telah dibuat.

4. Uji Coba Sistem

5. Implementasi dan Pemeliharan

Metode ARAS yang digunakan dalam penelitian ini, tahap-tahap algoritmanya dimulai dari tahap input hingga proses dituangkan dalam bentuk flowchart. Pada penelitian ini algoritma ARAS dirancang menggunakan 5 buah kriteria input, yaitu pedagogik, kepribadian, sosial, profesional, dan tanggung jawab [5]. Metode ARAS menghasilkan data nilai tingkat peringkat alternatif $(\mathrm{K})$, dengan tahapan perhitungan metode sebagai berikut:

1. Pembentukan Decicion Making Matrix

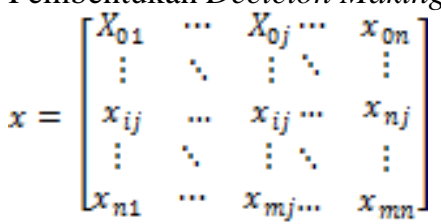

$i=m_{s} 0 ; j=1, n$

Dimana

$\mathrm{m}=$ jumlah alternatif

$\mathrm{n}=$ jumlah kriteria

$x i j=$ nilai performa dari alternatif $i$ terhadap kriteria $j$

$\mathrm{x} 0 \mathrm{j}=$ nilai optimum dari kriteria $\mathrm{j}$

Jika Nilai Optimal Kriteria j X0j tidak diketahui, maka:

$X_{0 j}=\frac{\max }{i} \cdot X_{i j}, i f \frac{\max }{i}$ is preferable

$X_{0 j}=\frac{\min }{i} \cdot X_{i j}, i f \frac{\text { min }}{i}$ is pref $a b l e$

2. Penormalisasian Decision Making Matrix untuk semua kriteria

Jika kriteria Beneficial (Benefit) maka dilakukan normalisasi mengikuti:

$X_{i j}^{*}=\frac{x_{i j}}{\sum_{i=0}^{m} x_{i j}}$

Dimana $X_{i j}^{*}$ adalah nilai normalisasi. 
Jika kriteria Non-Beneficial (Cost) maka dilakukan normalisasi mengikuti:

Langkah $1: X_{i j}^{*}=\frac{1}{X_{i j}}$ dan Langkah $2: R=\frac{X_{i j}^{*}}{\sum_{i=0}^{v m} X_{i j}^{*}}$

3. Menentukan bobot matriks yang sudah dinormalisasi

Dimana $\mathrm{W}_{\mathrm{j}}=$ bobot kriteria $\mathrm{j} D=\left[D_{i j}\right] m . n=R_{i j} . W_{j}$

4. Menentukan nilai dari fungsi optimalisasi $\left(\mathrm{S}_{\mathrm{i}}\right)$

$S_{i}=\sum_{j=1}^{n} D_{i j} ;(i=1,2 \ldots m ; j=1,2 \ldots n)$

Dimana $S_{i}$ adalah nilai fungsi optimalitas alternatif i. Nilai terbesar adalah yang terbaik, dan nilai yang paling sedikit adalah yang terburuk. Dengan memperhitungkan proses, hubungan proporsional dengan nilai dan bobot kriteria yang diteliti berpengaruh pada hasil akhir.

5. Menentukan tingkatan peringkat

$K_{\mathrm{i}=}=\frac{s_{\mathrm{i}}}{s_{0}}$

Dimana $S_{i}$ adalah nilai fungsi optimalitas alternatif i. Nilai terbesar adalah yang terbaik, dan nilai yang paling sedikit adalah yang terburuk. Dengan memperhitungkan proses, hubungan proporsional dengan nilai dan bobot kriteria yang diteliti berpengaruh pada hasil akhir [2].

\section{ANALISA DAN HASIL}

\subsection{Proses Pengolahan Data}

Ada lima kriteria penilaian yang digunakan dalam penelitian ini, yaitu pedagogik, kepribadian, sosial, professional, dan tanggung jawab. Berikut pembobotan tiap kriteria penilaian, terlihat pada tabel $1 \mathrm{~s} / \mathrm{d}$ tabel 6 .

\begin{tabular}{cccc}
\multicolumn{4}{c}{ Tabel 1.Tabel Bobot Kriteria } \\
\hline Kriteria & Keterangan & Jenis & Nilai Bobot Kriteria \\
\hline C1 & Pedagogik & Benefit & 20 \\
C2 & Kepribadian & Benefit & 25 \\
C3 & Sosial & Benefit & 15 \\
C4 & Profesional & Benefit & 10 \\
C5 & Tanggungjawab & Benefit & 30 \\
\hline
\end{tabular}

Tabel 2. Pembobotan Kriteria Pedagogik (C1)

\begin{tabular}{clcc}
\hline No & Kompetensi Pedagogik & Bobot & Keterangan \\
\hline 1 & Memenuhi 9 -10 kompetensi & 5 & Sangat Baik \\
2 & Memenuhi 7 - 8 kompetensi & 4 & Baik \\
3 & Memenuhi 5 -6 kompetensi & 3 & Cukup Baik \\
4 & Memenuhi 3 -4 kompetensi & 2 & Kurang Baik \\
5 & Memenuhi < 3 kompetensi & 1 & Buruk \\
\hline
\end{tabular}

Tabel 3. Pembobotan Kriteria Kepribadian (C2)

\begin{tabular}{cccc}
\hline No & Kompetensi Kepribadian & Bobot & Keterangan \\
\hline 1 & Memenuhi 1 kompetensi & 1 & Buruk \\
2 & Memenuhi 2 kompetensi & 2 & Kurang Baik \\
3 & Memenuhi 3 kompetensi & 3 & Cukup Baik \\
4 & Memenuhi 4 kompetensi & 4 & Baik \\
5 & Memenuhi 5 kompetensi & 5 & Sangat Baik \\
\hline
\end{tabular}

Tabel 4. Pembobotan Kriteria Sosial (C3)

\begin{tabular}{clcc}
\hline No & \multicolumn{1}{c}{ Kompetensi Sosial } & Bobot & Keterangan \\
\hline 1 & Tidak ada & 1 & Buruk \\
2 & Memenuhi 1 kompetensi & 2 & Kurang Baik \\
3 & Memenuhi 2 kompetensi & 3 & Cukup Baik \\
4 & Memenuhi 3 kompetensi & 4 & Baik \\
5 & Memenuhi 4 kompetensi & 5 & Sangat Baik \\
\hline
\end{tabular}

Tabel 5. Pembobotan Kriteria Profesional (C4)

\begin{tabular}{cccc}
\hline No & Kompetensi Profesional & Bobot & Keterangan \\
\hline 1 & Memenuhi 1 kompetensi & 1 & Buruk \\
2 & Memenuhi 2 kompetensi & 2 & Kurang Baik \\
\hline
\end{tabular}




\begin{tabular}{lllc}
\hline 3 & Memenuhi 3 kompetensi & 3 & Cukup Baik \\
4 & Memenuhi 4 kompetensi & 4 & Baik \\
5 & Memenuhi 5 kompetensi & 5 & Sangat Baik \\
\hline
\end{tabular}

Tabel 6. Pembobotan Kriteria Tanggung Jawab (C5)

\begin{tabular}{ccc}
\hline No & Tanggung Jawab & Bobot \\
\hline 1 & Buruk & 1 \\
2 & Kurang Baik & 2 \\
3 & Cukup Baik & 3 \\
4 & Baik & 4 \\
5 & Sangat Baik & 5 \\
\hline
\end{tabular}

Berdasarkan pembobotan dan penilaian yang dilakukan kepada tenaga pengajar di SMP Negeri 3 Satu Atap Selesai diperoleh hasil data alternatif yang telah dikonversipada tabel 7 sebagai berikut.

Tabel 7. Hasil Konversi Data Alternatif

\begin{tabular}{ccccccc}
\hline No & Alternatif & C1 & C2 & C3 & C4 & C5 \\
\hline 1 & A1 & 5 & 5 & 3 & 4 & 4 \\
2 & A2 & 4 & 4 & 4 & 5 & 5 \\
3 & A3 & 4 & 4 & 5 & 3 & 4 \\
4 & A4 & 5 & 4 & 4 & 5 & 5 \\
5 & A5 & 5 & 4 & 5 & 5 & 5 \\
6 & A6 & 3 & 3 & 4 & 2 & 1 \\
7 & A7 & 4 & 5 & 5 & 3 & 4 \\
8 & A8 & 5 & 5 & 5 & 5 & 4 \\
9 & A9 & 5 & 4 & 4 & 3 & 2 \\
10 & A10 & 5 & 5 & 5 & 4 & 5 \\
11 & A11 & 4 & 5 & 4 & 5 & 4 \\
12 & A12 & 4 & 4 & 5 & 4 & 4 \\
13 & A13 & 4 & 5 & 4 & 4 & 4 \\
14 & A14 & 3 & 4 & 5 & 4 & \\
\hline
\end{tabular}

Dari hasil konversi data alternatif, kemudian data alternative tersebut dinormalisasikan sesuai rumus yang metode ARAS. Berikut tabel 8 adalah nilai hasil normalisasi data.

Berikut tabel 9 dan tabel 10 merupakan proses perhitungan nilai optimal: dimana $\mathrm{w}$ (bobot kriteria) = $\{0,20$ untuk $\mathrm{C} 1 ; 0,25$ untuk $\mathrm{C} 2 ; 0,15$ untuk $\mathrm{C} 3 ; 0,10$ untuk $\mathrm{C} 4 ; 0,30$ untuk $\mathrm{C} 5\}$

Tabel 9. Hasil Bobot Kriteria

\begin{tabular}{cccccc}
\hline Alternatif & C1 & C2 & C3 & C4 & C5 \\
\hline A0 & 0,0153 & 0,0190 & 0,0112 & 0,0082 & 0,0255 \\
A1 & 0,0153 & 0,0190 & 0,0067 & 0,0065 & 0,0203 \\
A2 & 0,0123 & 0,0151 & 0,0089 & 0,0082 & 0,0255 \\
\hline
\end{tabular}




\begin{tabular}{|c|c|c|c|c|c|c|c|}
\hline A3 & 0,0123 & & 0,0151 & 0,0112 & \multicolumn{2}{|c|}{0,0049} & 0,0203 \\
\hline A4 & 0,0153 & & 0,0151 & 0,0089 & \multicolumn{2}{|c|}{0,0082} & 0,0255 \\
\hline A5 & 0,0153 & & 0,0151 & 0,0112 & \multicolumn{2}{|c|}{0,0082} & 0,0255 \\
\hline A6 & 0,0092 & & 0,0113 & 0,0089 & \multicolumn{2}{|c|}{0,0032} & 0,0051 \\
\hline A7 & 0,0123 & & 0,0190 & 0,0112 & \multicolumn{2}{|c|}{0,0049} & 0,0203 \\
\hline A8 & 0,0153 & & 0,0190 & 0,0112 & \multicolumn{2}{|c|}{0,0082} & 0,0203 \\
\hline A9 & 0,0153 & & 0,0151 & 0,0089 & \multicolumn{2}{|c|}{0,0049} & 0,0102 \\
\hline A 10 & 0,0153 & & 0,0190 & 0,0112 & \multicolumn{2}{|c|}{0,0065} & 0,0152 \\
\hline A11 & 0,0123 & & 0,0190 & 0,0089 & \multicolumn{2}{|c|}{0,0082} & 0,0254 \\
\hline A12 & 0,0123 & & 0,0151 & 0,0112 & \multicolumn{2}{|c|}{0,0065} & 0,0203 \\
\hline A13 & 0,0123 & & 0,0190 & 0,0089 & \multicolumn{2}{|c|}{0,0065} & 0,0203 \\
\hline A14 & 0,0092 & & 0,0151 & 0,0112 & \multicolumn{2}{|c|}{0,0065} & 0,0203 \\
\hline \multicolumn{8}{|c|}{ Tabel 10. Nilai Masing-Masing Alternatif } \\
\hline Alternatif & $\mathrm{C} 1$ & $\mathrm{C} 2$ & $\mathrm{C} 3$ & $\mathrm{C} 4$ & $\mathrm{C} 5$ & $\mathrm{~S}$ & $\mathrm{~K}$ \\
\hline $\mathrm{A} 0$ & 0,0125 & 0,0189 & 0,0112 & 0,0082 & 0,0254 & 0,0791 & 0,0791 \\
\hline A1 & 0,0156 & 0,0189 & 0,0067 & 0,0066 & 0,0203 & 0,0679 & 0,0679 \\
\hline A2 & 0,0125 & 0,0152 & 0,0090 & 0,0082 & 0,0254 & 0,0702 & 0,0702 \\
\hline A3 & 0,0125 & 0,0152 & 0,0112 & 0,0049 & 0,0203 & 0,0639 & 0,0639 \\
\hline A4 & 0,0156 & 0,0152 & 0,0090 & 0,0082 & 0,0254 & 0,0731 & 0,0731 \\
\hline A5 & 0,0156 & 0,0152 & 0,0112 & 0,0082 & 0,0254 & 0,0753 & 0,0753 \\
\hline A6 & 0,0094 & 0,0114 & 0,0090 & 0,0033 & 0,0051 & 0,0379 & 0,0379 \\
\hline A7 & 0,0125 & 0,0189 & 0,0112 & 0,0049 & 0,0203 & 0,0677 & 0,0677 \\
\hline A8 & 0,0156 & 0,0189 & 0,0112 & 0,0082 & 0,0203 & 0,0743 & 0,0743 \\
\hline A9 & 0,0156 & 0,0152 & 0,0090 & 0,0049 & 0,0102 & 0,0545 & 0,0545 \\
\hline A10 & 0,0156 & 0,0189 & 0,0112 & 0,0066 & 0,0153 & 0,0673 & 0,0673 \\
\hline A11 & 0,0125 & 0,0189 & 0,0090 & 0,0082 & 0,0254 & 0,0738 & 0,0738 \\
\hline A12 & 0,0125 & 0,0152 & 0,0112 & 0,0066 & 0,0203 & 0,0655 & 0,0655 \\
\hline A13 & 0,0125 & 0,0189 & 0,0090 & 0,0066 & 0,0203 & 0,0671 & 0,0671 \\
\hline A14 & 0,0094 & 0,0152 & 0,0112 & 0,0066 & 0,0203 & 0,0624 & 0,0624 \\
\hline
\end{tabular}

Berikut tabel 11 merupakan hasil perangkingan dari semua alternatif.

Tabel 11. Hasil Perangkingan

\begin{tabular}{ccc}
\hline Kode Alternatif & Nilai Akhir & Ranking \\
\hline A5 & 0,0753 & 1 \\
A8 & 0,0743 & 2 \\
A11 & 0,0738 & 3 \\
A4 & 0,0731 & 4 \\
A2 & 0,0702 & 5 \\
A1 & 0,0679 & 6 \\
A7 & 0,0677 & 7 \\
A10 & 0,0673 & 8 \\
A13 & 0,0671 & 9 \\
A12 & 0,0655 & 10 \\
A3 & 0,0639 & 11 \\
A14 & 0,0624 & 12 \\
A9 & 0,0545 & 13 \\
A6 & 0,0379 & 14 \\
\hline
\end{tabular}

\subsection{Proses Implementasi Sistem}

Berikut implementasi sistem dari proses penilaian kinerja tenaga pengajar yang dilakukan pada SMP Negeri 3 Satu Atap Selesai dengan metode ARAS.

Tampilan form login dapat dilihat pada gambar 1 dibawah ini.

a. Tampilan Form Login 


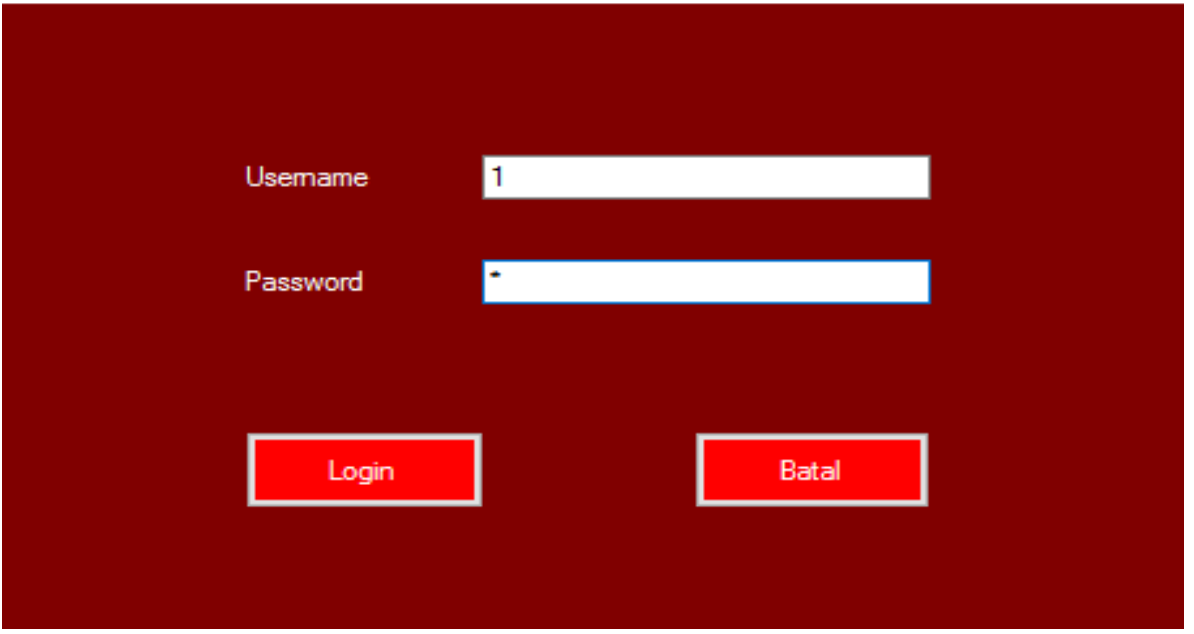

Gambar 1. Form Login

Tampilan form alternatif dapat dilihat pada gambar 2 dibawah ini. b. Tampilan Halaman Input Data Alternatif

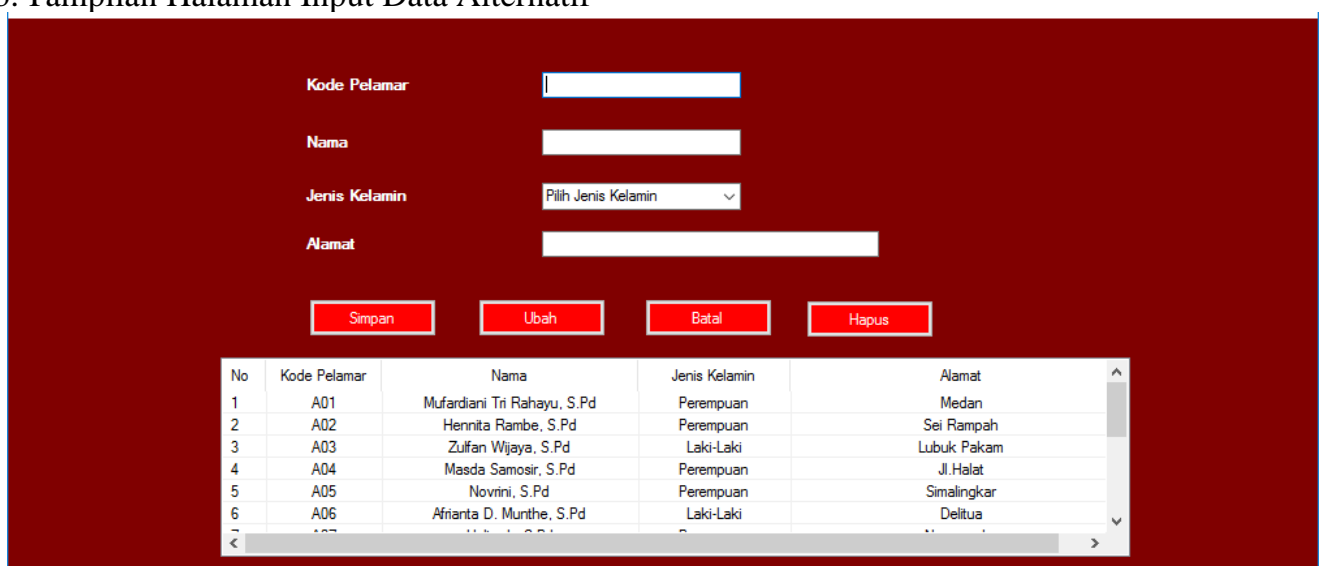

Gambar 2. Tampilan Menu Input Data Alternatif

Tampilan form kriteria dapat dilihat pada gambar 3 dibawah ini. c. Tampilan Halaman Kriteria

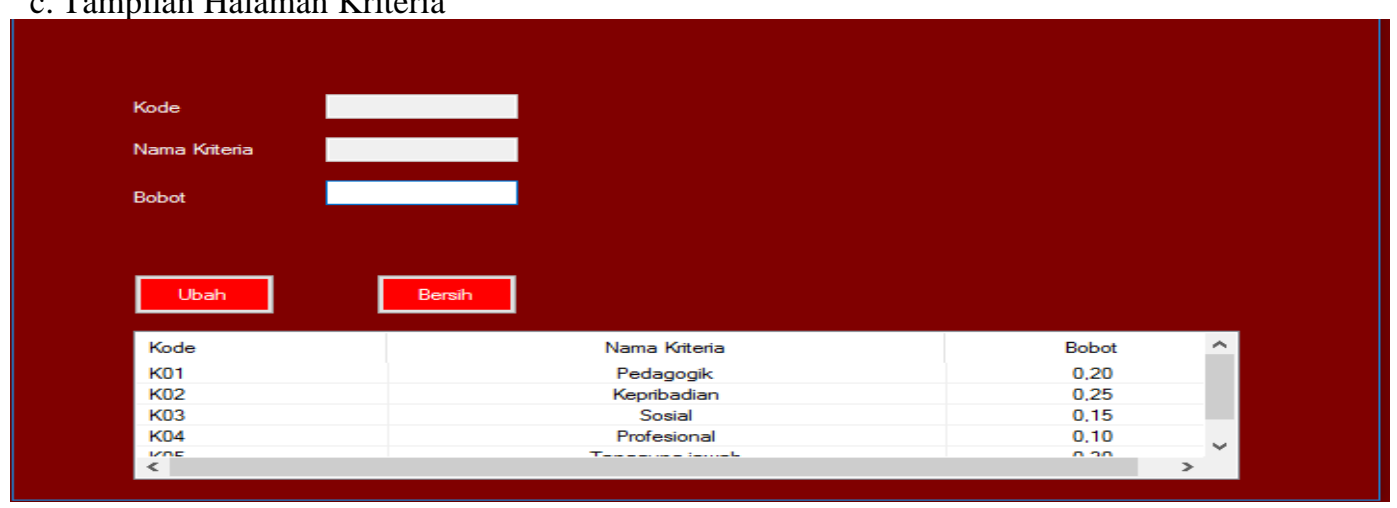

Gambar 3. Tampilan Menu Kriteria

Tampilan form penilaian dapat dilihat pada gambar 4 dibawah ini. d. Tampilan Halaman Penilaian 

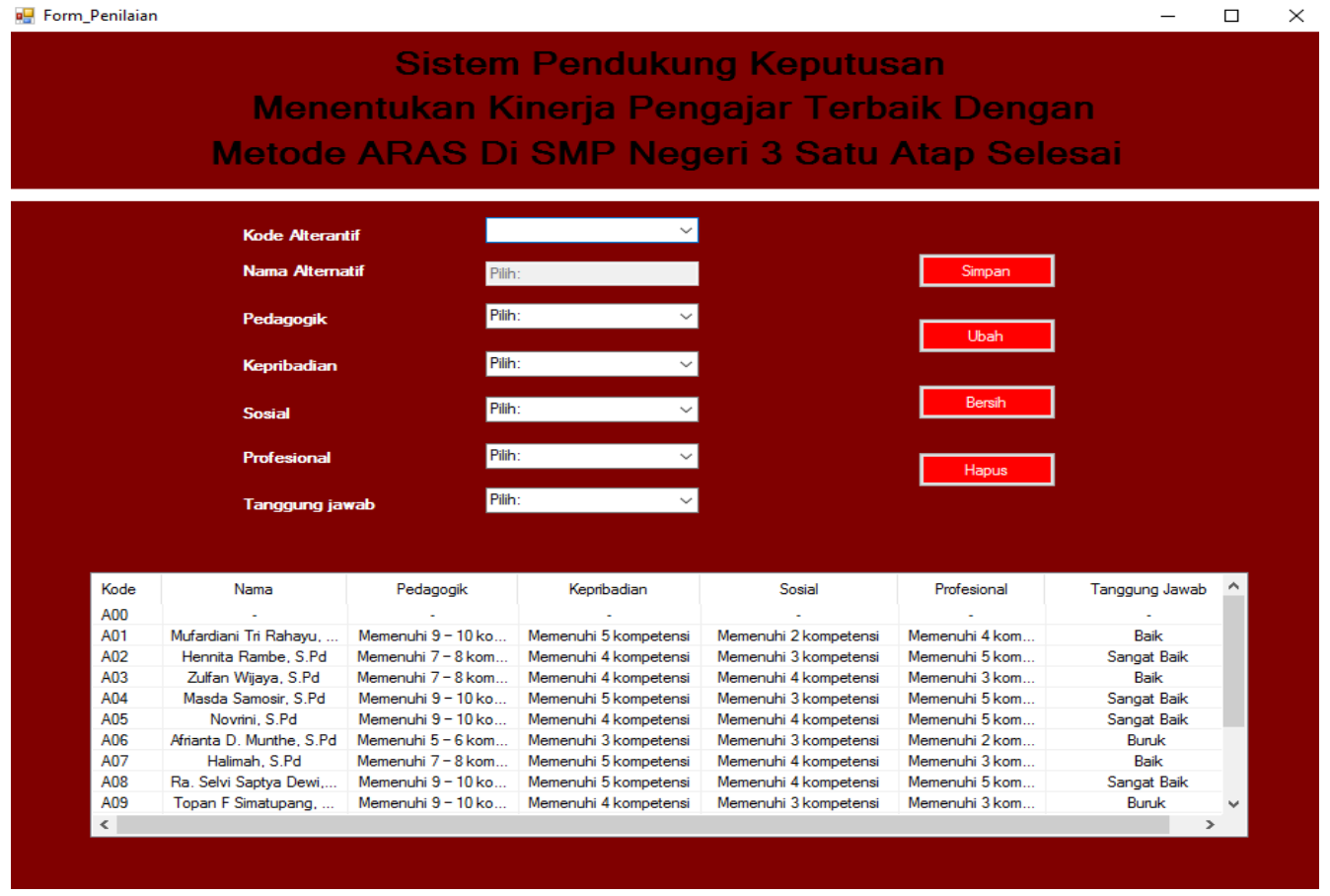

Gambar 4. Tampilan Halaman Penilaian

Tampilan form proses dapat dilihat pada gambar 5 dibawah ini.

e. Tampilan Halaman Proses

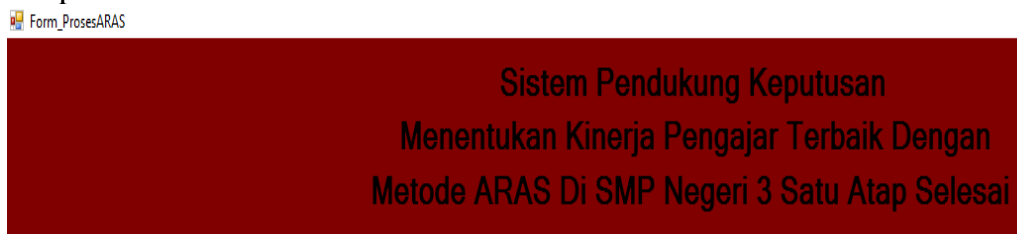

- $0 x$

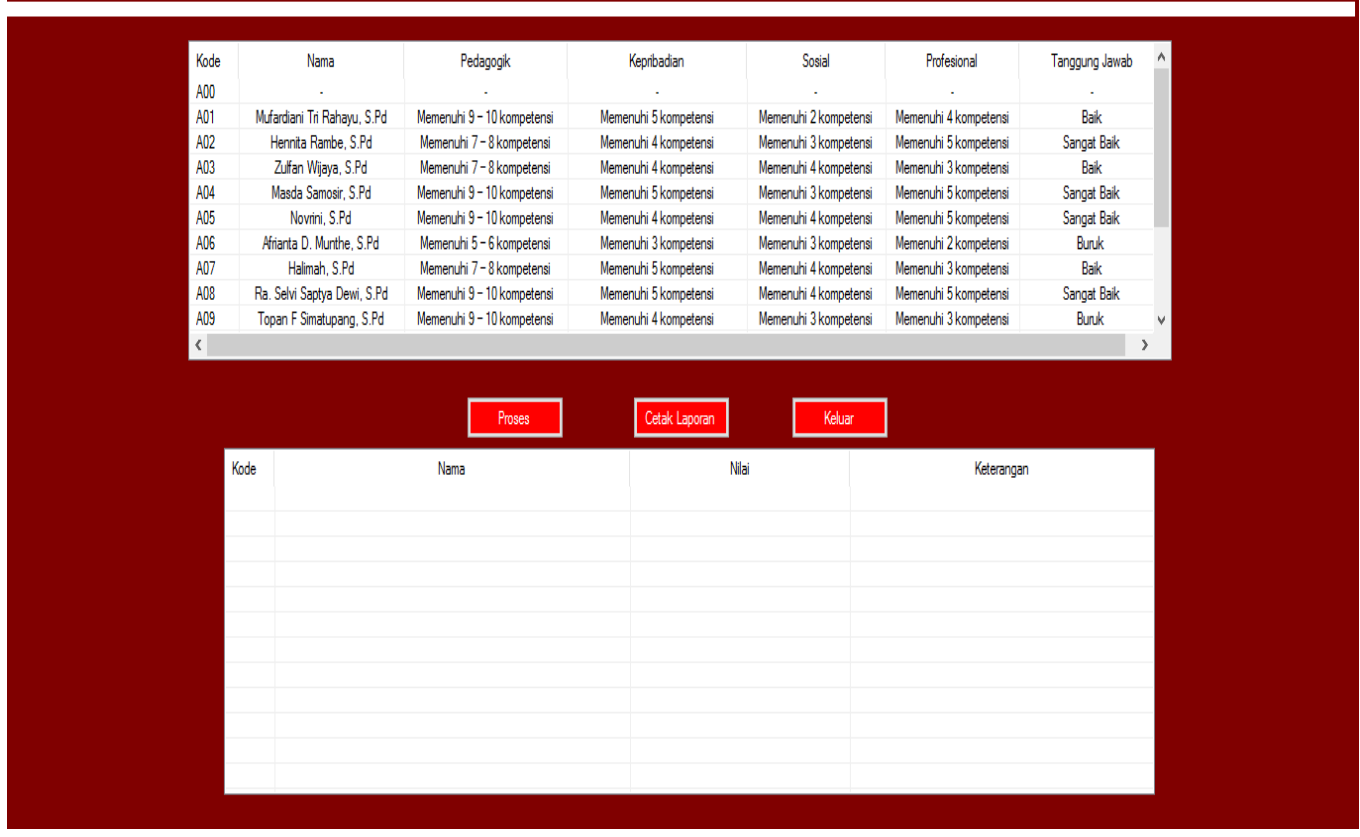

Gambar 5. Tampilan Halaman Proses

Tampilan form laporan dapat dilihat pada gambar 6 dibawah ini. 


\section{Sistem Pendukung Keputusan Menentukan Kinerja Pengajar Terbaik di SMP NEGERI 3 SATU ATAP SELESAI dengan Metode ARAS}

\begin{tabular}{|c|c|c|c|c|}
\hline No & kode & nama & nillai & keterangan \\
\hline 1 & $\mathrm{~A} 00$ & - & 0,07914 & - \\
\hline 2 & $A 05$ & Novrini, S.Pd & 0.07535 & Rangking 1 \\
\hline 3 & $\mathrm{~A} 08$ & Ra. Selvi Saptya Dew & 0,07405 & Rangking 2 \\
\hline 4 & A11 & Berliana Sitorus, SPd & 0,07384 & Rangking 3 \\
\hline 5 & $\mathrm{~A} 04$ & Masda Samosir, SPd & 0,07312 & Rangking 4 \\
\hline 6 & $\mathrm{~A} 02$ & Hennita Rambe, SPd & 0,07005 & Rangking 5 \\
\hline 7 & $\mathrm{~A} 01$ & Mufardiani TriRahayu & 0,06794 & Rangking 6 \\
\hline 8 & $\mathrm{~A} 07$ & $\mathrm{Halimah,} \mathrm{S.Pd}$ & 0.0677 & Rangking 7 \\
\hline 9 & A10 & Syamsiah, S.Pd & 0,06733 & Rangking 8 \\
\hline 10 & $\mathrm{~A} 06$ & Afrianta D. Munthe S.t & 0.06711 & Rangking 9 \\
\hline 11 & A12 & Nur Azizah, S.Pd & 0,06555 & Rangking 10 \\
\hline 12 & $\mathrm{~A} 03$ & Zulfan Wijaya, SPd & 0.06391 & Rangking 11 \\
\hline 13 & A14 & Fera J Eprananta SBR & 0,06247 & Rangking 12 \\
\hline 14 & $\mathrm{~A} 09$ & Topan F Simatupang. : & 0,05458 & Rangking 13 \\
\hline 15 & A13 & Medyanita F Br. Gintin & 0.03792 & Rangking 14 \\
\hline \multicolumn{5}{|c|}{ Langkat, ........ } \\
\hline
\end{tabular}

Gambar 6. Hasil Laporan

Sebelum masuk dan mengakses aplikasi admin harus melakukan login terlebih dahulu dengan cara menginput username dan password, jika benar admin akan masuk kehalaman menu utama dan jika username dan password yang diinputkan tidak sesuai maka admin harus mengulangi untuk menginput username dan password dengan benar. Setelah login admin dapat mengisi penilaian tenaga pengajar dan memperoleh hasil penilaian. Dari hasil penilaian didapat peringkat kinerja tenaga pengajar. Berdasarkan hasil perhitungan manual yang dilakukan dengan metode ARAS memiliki nilai yang sama dengan hasil perhitungan dengan sistem. Hal ini menunjukkan bahwa sistem pendukung keputusan dengan metode ARAS yang dilakukan dapat digunakan untuk menentukan keputusan kinerja terbaik. Dengan menggunakan sistem pendukung keputusan ini dapat memudahkan Kepala Sekolah dalam mengolah hasil evaluasi tenaga pengajar.

\section{KESIMPULAN}

Dari penelitian dan pengujian yang telah dilakukan diperoleh kesimpulan antara lain: sistem pendukung keputusan dengan metode ARAS dirancang berbasis sistem operasi Microsoft windows dan bahasa pemrograman Microsoft visual studio dapat menentukan urutan kinerja tenaga pengajar dari yang terbaik. Dari hasil pengujian tenaga pengajar yang bernama Novrini, S.Pd merupakan tenaga pengajar yang memiliki kinerja terbaik di SMP Negeri 3 Satu Atap Selesai karena memiliki nilai tertinggi dalam kriteria pada sistem.

\section{UCAPAN TERIMA KASIH}

Peneliti mengucapkan terima kasih kepada Ibu Erika Fahmi Ginting, S.Kom., M.Kom dan Bapak Rendy Syahputra yang telah memberikan bimbingan selama penelitian hingga penyelesaian penulisan 
artikel ini. Terima kasih juga kepada Ibu Asnah Br. Sembiring, S.Pd yang telah mengizinkan penulis untuk meneliti di SMP Negeri 3 Satu Atap Selesai.

\section{REFERENSI}

[1] D. S. Lubis, "Sistem Pendukung Keputusan Pemilihan Trainer Menggunakan Metode ARAS (Additive Ratio Assessment)," pp. 448-455, 2019.

[2] E. K. Zavadskas and Z. Turskis, "A new addtive ratio assessment (ARAS) method in multicriteria decision-making," Technol. Econ. Dev. Econ., vol. 16, no. 2, pp. 159-172, 2010.

[3] J. Afriany and Lijayani, "Penerapan Metode ARAS Guna Mendukung Keputusan Produk Unggulan Daerah," Sainteks, pp. 441-447, 2019.

[4] D. T. Azmi, "Sistem Pendukung Keputusan Pemilihan Polisi Militer Terbaik Menggunakan Metode Additive Ratio Assessment ( ARAS ) ( Studi Kasus : Detasement Polisi Militer ( Denpom ) I / 5 Medan," vol. 7, no. 2, pp. 159-164, 2020.

[5] Departemen Pendidikan Nasional, Undang - Undang No 16 Tahun 2007 Tentang Standar Kualifikasi Akademik dan Kompetensi Guru. Jakarta: Depdiknas, 2007.

\section{BIBLIOGRAFI PENULIS}

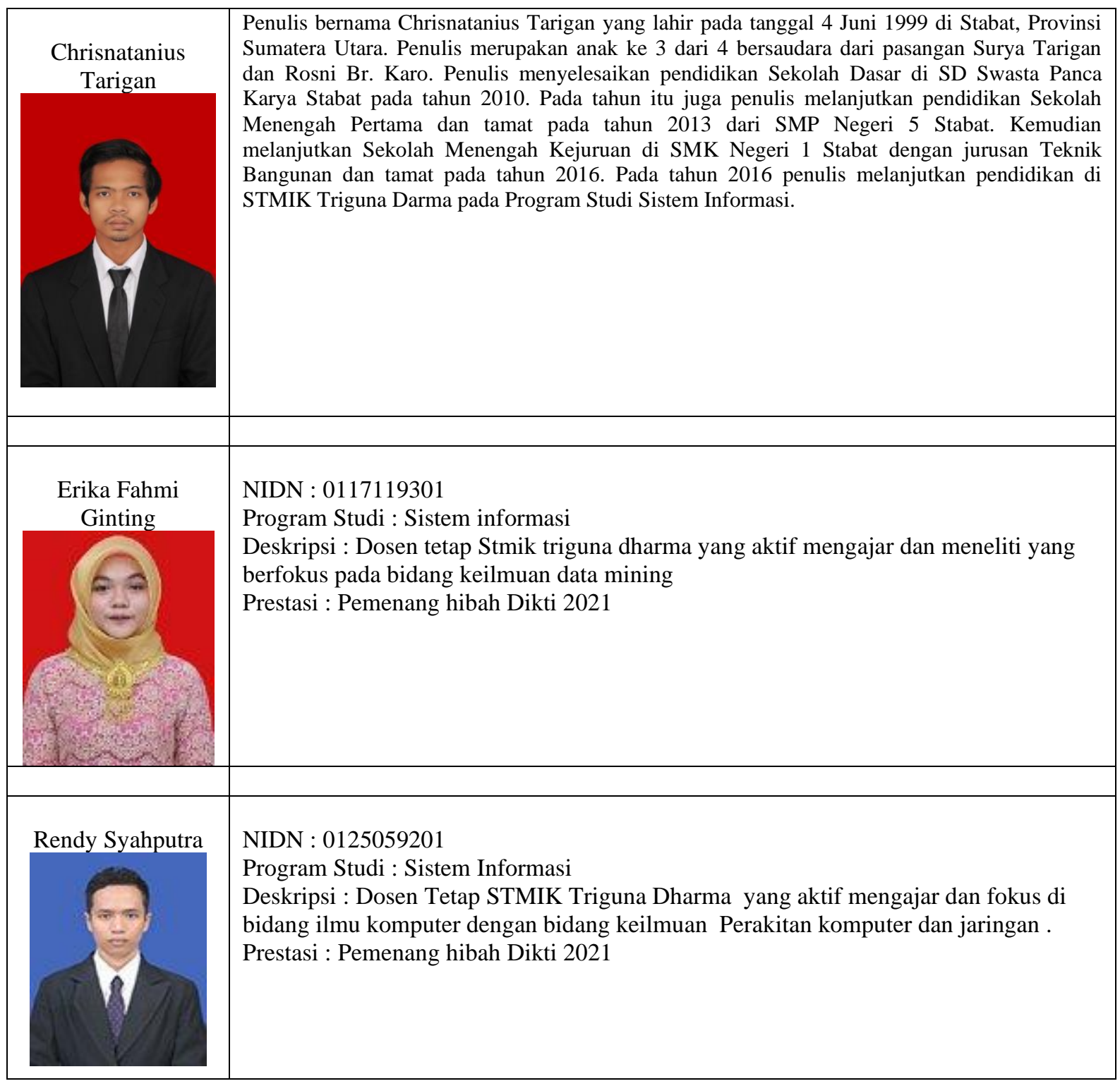

